\title{
Linkage and Branch Analysis of High-Mannose Oligosaccharides Using Closed-Ring Labeling of 8-Aminopyrene-1,3,6-Trisulfonate and $P$-Aminobenzoic Ethyl Ester and Negative Ion Trap Mass Spectrometry
}

\author{
Shu-Ting Chen, Guor-Rong Her
}

Department of Chemistry, National Taiwan University, Taipei, Taiwan

\begin{abstract}
A strategy based on negative ion electrospray ionization tandem mass spectrometry and closedring labeling with both 8-aminopyrene-1,3,6-trisulfonate (APTS) and $p$-aminobenzoic acid ethyl ester (ABEE) was developed for linkage and branch determination of high-mannose oligosaccharides. X-type cross-ring fragment ions obtained from APTS-labeled oligosaccharides by charge remote fragmentation provided information on linkages near the non-reducing terminus. In contrast, A-type cross-ring fragment ions observed from ABEE-labeled oligosaccharides yielded information on linkages near the reducing terminus. This complementary information provided by APTS- and ABEE-labeled oligosaccharides was utilized to delineate the structures of the high-mannose oligosaccharides. As a demonstration of this approach, the linkages and branches of high-mannose oligosaccharides Man ${ }_{5} \mathrm{GlcNAc}_{2}, \operatorname{Man}_{6} \mathrm{GlcNAc}_{2}$, $\mathrm{Man}_{8} \mathrm{GlcNAc}_{2}$, and $\mathrm{Man}_{9} \mathrm{GICNAc_{2 }}$ cleaved from the ribonuclease $\mathrm{B}$ were assigned from $\mathrm{MS}^{2}$ spectra of ABEE- and APTS-labeled derivatives.
\end{abstract}

Key words: N-linked oligosaccharides, High-mannose oligosaccharides, 8-Aminopyrene-1,3,6trisulfonate, $p$-Aminobenzoic acid ethyl ester, Linkage, Electrospray, Closed-Ring Labeling

\section{Introduction}

G lycosylation is a predominant post-translational modification as $50 \%$ of mammalian proteins are glycosylated [1-6]. The structural diversity inherent in the sugar moieties of a glycoprotein results in subtle changes in protein shape and charge, ultimately affecting protein function, both temporally and spatially.

Electronic supplementary material The online version of this article (doi:10.1007/s13361-012-0420-0) contains supplementary material, which is available to authorized users.

Correspondence to: Guor-Rong Her; e-mail: grher@ntu.edu.tw
Mass spectrometry is one of the most powerful and versatile tools for structural analysis of carbohydrates [7]. Soft ionization techniques such as matrix-assisted laser desorption/ionization (MALDI) and electrospray ionization (ESI) are now the most popular ionization methods used in carbohydrate structural analysis [8-38].

Metal ion coordination [13-15], permethylation [16-20, 31-38], reducing-end labeling [21-30], or underivatized glycans [9-12] in combination with tandem mass spectrometry are among reported strategies to produce linkage and branch information. Among these approaches, analysis of permethylated glycans by MALDI-TOF/TOF is quite useful [31-38]. Unfortunately, it requires the use of high-energy 
collision-induced dissociation (he-CID), which is not available in many laboratories studying oligosaccharides.

Negative ion spectra of underivatized oligosaccharides could produce many linkage specific fragment ions. However, for oligosaccharides larger than a hexasaccharide, the use of $\mathrm{MS}^{3}$ or $\mathrm{MS}^{4}$ is needed. In addition, linkage information on non-reducing end and the linkage information on the 3-linked branch are prone to miss [9-12]. The fragmentation patterns of closed-ring labeled and underivatized oligosaccharides are very similar [9-12, 22]. However, our earlier study of ABEE-labeled oligosaccharides by negative ion ESI showed that MS sensitivity was enhanced and a more clear assignment for the linkages was obtained [22, 28]. Unfortunately, for oligosaccharides larger than a hexasaccharide, linkages near the non-reducing end were not observed. To extend this ABEE approach to larger oligosaccharides, a procedure involving alkaline degradation was introduced prior to labeling and $\mathrm{MS}^{\mathrm{n}}$ analysis. Consequently, linkage and branch information near the non-reducing end were obtained [29].

To provide linkage information near the non-reducing end of oligosaccharide, fragmentation near the non-reducing end is required. Trimethyl( $p$-aminophenyl)ammonium (TMAPA), a fixed-charged derivative, has been studied as a labeling reagent for oligosaccharide analysis [39]. Fragmentation is observed exclusively at the non-reducing terminus with charge retention on the TMAPA label at the reducing terminus. Based on this concept, oligosaccharides were separately labeled with both ABEE and the fixedcharge derivative, 8-aminopyrene-1,3,6-trisulfonate (APTS), before negative ESI-MS/MS analysis. The complementary information provided by ABEE- and APTS-labeled oligosaccharides was utilized to elucidate the structure of oligosaccharides larger than a hexasaccharide. The potential of this combined approach was demonstrated using the highmannose glycans cleaved from ribonuclease B.

\section{Experimental}

\section{Materials}

p-Aminobenzoic acid ethyl ester, maltohexaose, kojibiose, and ribonuclease B were purchased from Sigma-Aldrich Chemical Co. (St. Louis, MO, USA). 8-Aminopyrene-1,3,6trisulfonate was purchased from Fluka (Buchs, Switzerland). Laminarihexaose and isomaltohexaose were purchased from Seikagaku Kogyo (Tokyo, Japan). Peptide-N-glycanase F (PNGase F) was purchased from Roche Biochemicals (Basel, Switzerland). Glacial acetic acid, methanol, and acetonitrile were purchased from J. T. Baker (Phillipsburg, NJ, USA). Deionized (18M $\Omega$ ) water (Milli-Q water system, Millipore Inc., Bedford, MA, USA) was used in the preparation of the samples and reaction solution.

\section{Preparation of N-Linked Glycans}

The N-linked glycans were released enzymatically from ribonuclease $\mathrm{B}$ by means of PNGase $\mathrm{F}$ digestion and purified by using graphitized carbon cartridges (Alltech Associates, Lancashire, UK) [40, 41] and evaporated to dryness.

\section{Preparation of Closed-Ring Chromophore Labeled Derivatives}

For APTS labeling, dried oligosaccharides were derivatized by the addition of $2 \mu \mathrm{L} 0.02 \mathrm{M}$ APTS in $25 \%$ acetic acid and $10 \mu \mathrm{L}$ deionized water in an Eppendorf tube. The solution was kept at $75{ }^{\circ} \mathrm{C}$ for $6 \mathrm{~h}$. The derivatives were purified by passing through a column made of Sephadex G25 (Sigma) using water as the eluent, followed by lyophilization. For ABEE labeling, dried glycans were derivatized by using the glycosylamine approach [29].

\section{Electrospray Mass Spectrometry}

All mass spectrometry experiments were performed using a Finnigan LTQ ion trap mass spectrometer (Thermo Finnigan, San Jose, CA, USA) under negative ion electrospray. Samples were infused by syringe pump at a rate of $200 \mathrm{~nL} / \mathrm{min}$. The heated capillary was maintained at $275^{\circ} \mathrm{C}$ for all experiments. For massanalyzer collision-induced dissociation (CID), relative collision energy of $35 \%-50 \%$ was used in $\mathrm{MS}^{2}$ experiments.

\section{Results and Discussion}

\section{The Linkage Analysis of APTS-Labeled Oligosaccharides}

A typical negative ESI mass spectrum of APTS-labeled oligosaccharide (spectrum not shown) is characterized by the doubly and triply charged molecular ions along with the sodiated adducts. The $[\mathrm{M}-3 \mathrm{H}+\mathrm{Na}]^{2-}$ ion was chosen as the precursor ion because it produced more linkage related crossring cleavage fragments when compared to $\mathrm{MS}^{2}$ analysis of the $[\mathrm{M}-2 \mathrm{H}]^{2-}$ and $[\mathrm{M}-3 \mathrm{H}]^{3-}$ ions (data not shown).

Kojibiose, laminarihexaose, maltohexaose, and isomaltohexaose are 1-2, 1-3, 1-4, and 1-6 linked linear oligosaccharides, respectively. They were closed-ring labeled with APTS and studied by negative ion ESI-MS ${ }^{2}$ (Figures 1 and 2). The results revealed that the fragmentation patterns of APTS-labeled oligosaccharides occurred primarily via charge-remote fragmentation. As a result, linkage information starting at the non-reducing end was provided. A summary of the observed linkage specific fragment ions is shown in Table 1. Owing to the lack of a standard containing an internal 1-2 linkage, ions specific for internal 1-2 linkages were not assigned.

\section{Analysis of $\mathrm{Man}_{5} \mathrm{GlcNAc}_{2}$ Based on ABEE and APTS-Labeling}

For oligosaccharides larger than a hexasaccharide, such as $\mathrm{Man}_{5} \mathrm{GlcNAc}_{2}$, the linkages near the reducing-end 
(a)

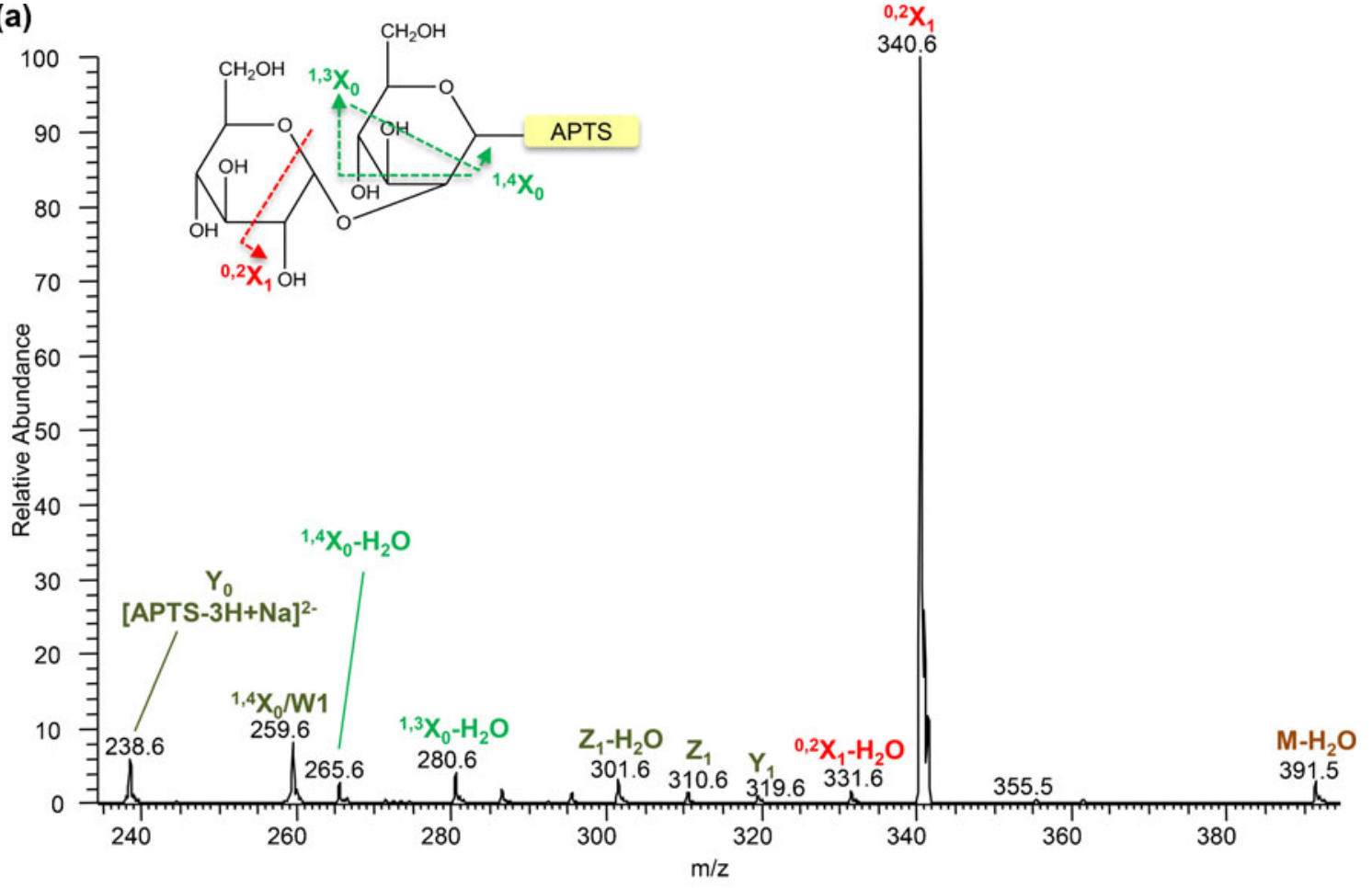

(b)

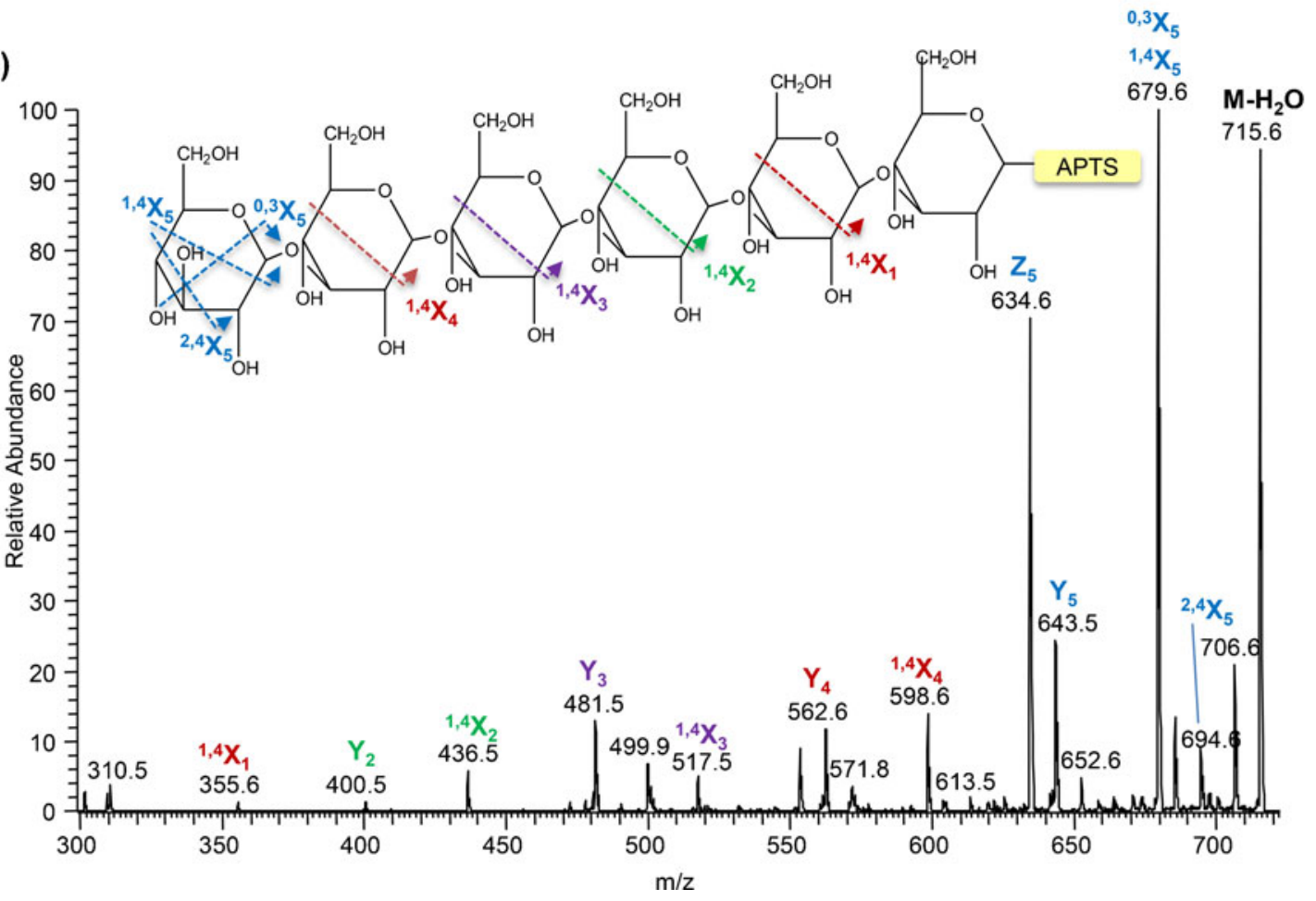

Figure 1. $M S^{2}$ negative ESI mass spectra of APTS-labeled oligosaccharides. (a) $\mathrm{MS}^{2}$ spectrum of APTS-labeled kojibiose $\left(\left[\mathrm{M}-3 \mathrm{H}+\mathrm{Na}^{2-}, \mathrm{m} / \mathrm{z} 400.5\right)\right.$. (b) $\mathrm{MS}^{2}$ spectrum of APTS-labeled laminarihexaose $\left([\mathrm{M}-3 \mathrm{H}+\mathrm{Na}]^{2-}, \mathrm{m} / \mathrm{z} 724.5\right)$. The specific fragment ions were assigned based on the nomenclature proposed by Domon and Costello [43]

could not be determined based on the spectrum of APTS labeling (Figure 3b). A strategy incorporating both APTS and $\mathrm{ABEE}$ labeling was employed to assign all linkages of $\mathrm{Man}_{5} \mathrm{GlcNAc}_{2}$. 


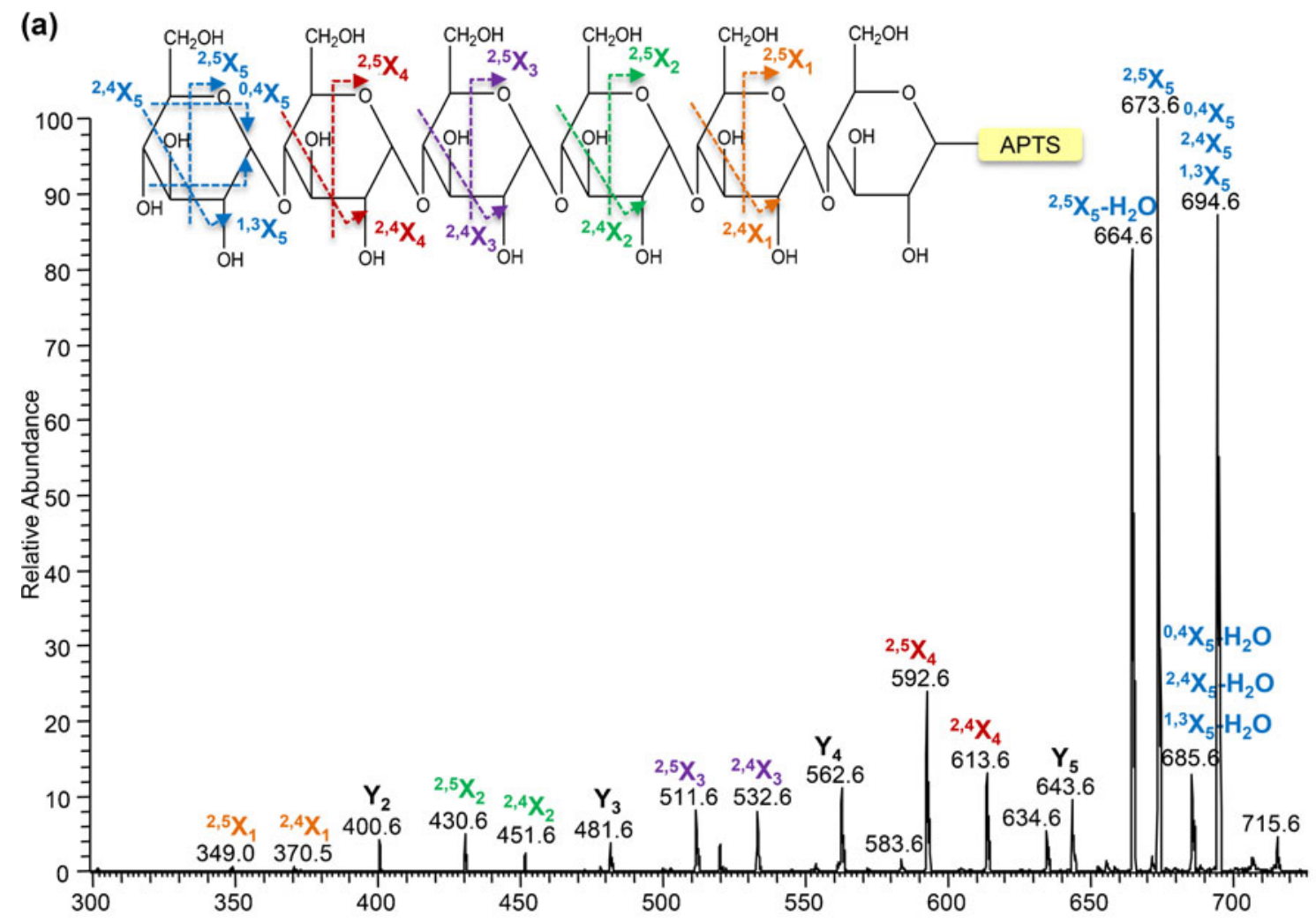

(b)

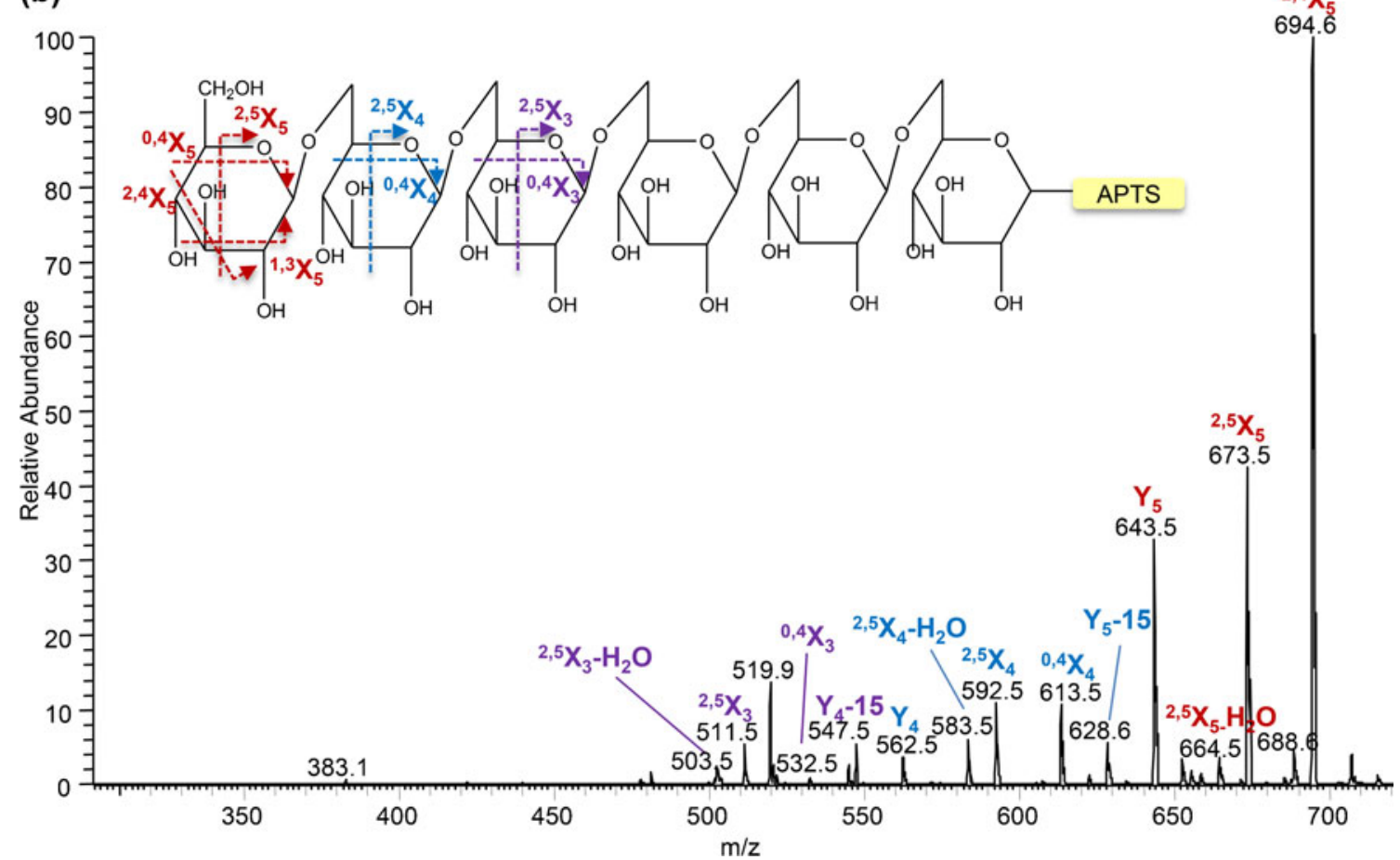

Figure 2. (a) $\mathrm{MS}^{2}$ spectrum of APTS-labeled maltohexaose $\left([\mathrm{M}-3 \mathrm{H}+\mathrm{Na}]^{2-}, \mathrm{m} / \mathrm{z}\right.$ 724.6). (b) $\mathrm{MS}^{2}$ spectrum of APTS-labeled isomaltohexaose $\left([\mathrm{M}-3 \mathrm{H}+\mathrm{Na}]^{2-}, \mathrm{m} / \mathrm{z} 724.5\right)$

The MS ${ }^{2}$ spectrum of ABEE-labeled $\mathrm{Man}_{5} \mathrm{GlcNAc}_{2}$ is shown in Figure 3a. It is noted that the linkage assignment of
ABEE-labeled $\mathrm{Man}_{5} \mathrm{GlcNAc}_{2}$ has previously been reported [29]. The fragment ions ${ }^{0,2} \mathrm{~A}_{5}-18(\mathrm{~m} / \mathrm{z} 1114.2),{ }^{0,2} \mathrm{~A}_{4}(\mathrm{~m} / \mathrm{z}$ 
Table 1. Specific Linkage Fragment Ions for APTS Closed-Ring Labeled Linear Oligosaccharides

\begin{tabular}{llc}
\hline Linkage & \multicolumn{1}{c}{ Fragments of the terminal linkage } & Fragments other than the reducing end \\
\hline $1-2$ & ${ }^{0,2} \mathrm{X},{ }^{0,2} \mathrm{X}-\mathrm{H}_{2} \mathrm{O}$ & $\mathrm{N} / \mathrm{A}$ \\
$1-3$ & ${ }^{2,4} \mathrm{X},{ }^{0,3} \mathrm{X}\left(\right.$ or $\left.{ }^{1,4} \mathrm{X}\right)$ & ${ }^{2,4} \mathrm{X}$ \\
$1-4$ & ${ }^{2,4} \mathrm{X}\left(\right.$ or ${ }^{1,3} \mathrm{X}$ or $\left.{ }^{0,4} \mathrm{X}\right),{ }^{2,4} \mathrm{X}-\mathrm{H}_{2} \mathrm{O}\left(\right.$ or ${ }^{1,3} \mathrm{X}-\mathrm{H}_{2} \mathrm{O}$ or $\left.{ }^{0,4} \mathrm{X}-\mathrm{H}_{2} \mathrm{O}\right),{ }^{2,5} \mathrm{X},{ }^{2,5} \mathrm{X}-\mathrm{H}_{2} \mathrm{O}$ & ${ }^{2,4} \mathrm{X},{ }^{2,5} \mathrm{X}$ \\
$1-6$ & ${ }^{0,4} \mathrm{X}\left(\right.$ or ${ }^{1,3} \mathrm{X}$ or $\left.{ }^{2,4} \mathrm{X}\right),{ }^{2,4} \mathrm{X},{ }^{2,5} \mathrm{X}-\mathrm{H}_{2} \mathrm{O}$ & ${ }^{2,5} \mathrm{X}, 15,{ }^{2,5} \mathrm{X}-\mathrm{H}_{2} \mathrm{O}$ \\
\hline
\end{tabular}

929.2), and ${ }^{0,2} \mathrm{~A}_{4}-18(\mathrm{~m} / \mathrm{z}$ 911.2) indicated that the first two linkages were 1-4 linkages. The mass difference between $\mathrm{C}_{3}\left(\mathrm{~m} / \mathrm{z}\right.$ 827.1) and $\mathrm{C}_{3} / \mathrm{Z}_{3 \beta}-\mathrm{H}(\mathrm{m} / \mathrm{z}$ 647.1) ion represents a 3-linked Hex connected to the first branch. The fragment ions $\mathrm{C}_{3} / \mathrm{Z}_{3 \beta}-\mathrm{H}-18(\mathrm{~m} / z \quad 629.2),{ }^{0,3} \mathrm{~A}_{3}(\mathrm{~m} / \mathrm{z}$ 575.1), and ${ }^{0,4} \mathrm{~A}_{3} \quad(\mathrm{~m} / z \quad 545.3)$ revealed that the first branch has a 3-,6-linked sugar.

The linkages near the non-reducing terminal were deduced from the $\mathrm{MS}^{2}$ spectrum of APTS-labeled $\mathrm{Man}_{5} \mathrm{GlcNAc}_{2}$ (Figure 3b). The fragment ions at $m / z 816.6\left({ }^{0,4} \mathrm{X}_{4 \alpha^{\prime}}\right), m / z$ $795.6\left({ }^{2,5} \mathrm{X}_{4 \alpha^{\prime}}\right)$ and $m / z 786.6\left({ }^{2,5} \mathrm{X}_{4 \alpha^{\prime}}-\mathrm{H}_{2} \mathrm{O}\right)$ suggested that one of the terminal mannose moieties binds by a 1-6 glycosyl bond. In addition, two series of terminal 1-3 linked characteristic ions were observed. The ions at $m / z 735.2\left({ }^{2,4} \mathrm{X}_{4 "} / \mathrm{Y}_{4 \alpha^{\prime}}\right)$ and $m / z$ $720.6\left({ }^{0,3} \mathrm{X}_{4 "} / \mathrm{Y}_{4^{\prime}}\right)$ represent a 1-3 linked terminal mannose with the loss of a monosaccharide. The ions at $\mathrm{m} / \mathrm{z} 574.6$ $\left({ }^{2,4} \mathrm{X}_{3 \beta} / \mathrm{Y}_{3 \alpha}\right)$ and $m / \mathrm{z} 560.5\left({ }^{0,3} \mathrm{X}_{3 \beta} / \mathrm{Y}_{3 \alpha}\right)$ represent a 1-3 linked terminal mannose with the loss of a trisaccharide. The $\mathrm{C}_{2 \alpha}$ ion $\left(\mathrm{m} / z\right.$ 503.1) in Figure $3 \mathrm{a}$ and $\mathrm{Z}_{3 \alpha}$ ion $(\mathrm{m} / \mathrm{z} 595.1)$ in Figure $3 \mathrm{~b}$ suggested that a trisaccharide is connected to the 6-arm of the first branch. Therefore, these two ions were assigned as the cross-ring cleavage ions from the 3-linked mannose connected to the first branch. The 1-6 linked terminal and the second 1-3 linked terminal sugar were assigned as connected to the 6-arm of the first branch. As a result, a second branch point connected to the 6-arm of the first branched sugar was assigned as a 1-3 and 1-6 linked mannose.

\section{Analysis of $\mathrm{Man}_{6} \mathrm{GlcNAc}_{2}$ Based on ABEE and APTS-Labeling}

The $\mathrm{MS}^{2}$ spectrum of ABEE-labeled $\mathrm{Man}_{6} \mathrm{GlcNAc}_{2}$ is shown in Figure $4 \mathrm{a}$. The assignment is similar to $\mathrm{Man}_{5} \mathrm{GlcNAc}_{2}$, except that the mass difference between $\mathrm{C}_{3}\left(\mathrm{~m} / z\right.$ 989.2) and $\mathrm{C}_{3} / \mathrm{Z}_{3 \beta}-\mathrm{H}(\mathrm{m} / z$ 647.1) ion (342 Da) suggested that a disaccharide was connected to the 3-branch.

The MS ${ }^{2}$ spectrum of APTS-labeled $\mathrm{Man}_{6} \mathrm{GlcNAc}_{2}$ is shown in Figure 4b. In addition to the terminal 1-3 and 1-6 linked mannoses as in $\mathrm{Man}_{5} \mathrm{GlcNAc}_{2}$, a 1-2 linked terminal mannose was assigned by the characteristic ions ${ }^{0,2} \mathrm{X}_{4 \beta} / \mathrm{Y}_{3 \alpha} \quad(m / z \quad 624.3)$ and ${ }^{0,2} \mathrm{X}_{4 \beta}-\mathrm{H}_{2} \mathrm{O} / \mathrm{Y}_{3 \alpha} \quad(m / z$ 614.8). The characteristic ion ${ }^{2,5} \mathrm{X}_{3 \alpha}(\mathrm{m} / \mathrm{z}$ 715.4) suggested that the second branch did not contain a 1-2 linked mannose, therefore, the 2-linked terminal mannose was assigned as the terminal sugar of the 3-linked disaccharide in the first branch. The observed 1-3 linked internal fragments ${ }^{1,4} \mathrm{X}_{3 \beta} / \mathrm{Y}_{3 \alpha}(m / z$ 560.7) was assigned as the 3-linked disaccharide connected to the first branch. Other assignments were similar to $\mathrm{Man}_{5} \mathrm{GlcNAc}_{2}$.

\section{Analysis of $\mathrm{Man}_{8} \mathrm{GlcNAc}_{2}$ Based on APTS and $A B E E$-Labeling}

The $\mathrm{Man}_{8} \mathrm{GlcNAc}_{2}$ is a mixture of three structural isomers with a molar ratio of $\sim 84: 6: 10$ [42]. Because of the much higher abundance of one isomer ( $84 \%)$, the fragmentation is expected to be predominated by this isomer.

The $\mathrm{MS}^{2}$ spectrum of ABEE-labeled $\mathrm{Man}_{8} \mathrm{GlcNAc}_{2}$ (Supplemental Figure S1) is similar to $\mathrm{Man}_{6} \mathrm{GlcNAc}_{2}$ (Figure 4a). The mass difference between $\mathrm{C}_{4}(\mathrm{~m} / \mathrm{z}$ 1313.2) and $\mathrm{C}_{4} / \mathrm{Z}_{3 \beta}-\mathrm{H}(\mathrm{m} / z$ 809.2) ion (504 Da) suggested that the 3 -arm was substituted with a trisaccharide. In addition, the fragment ion $\mathrm{C}_{3 \alpha}(\mathrm{m} / \mathrm{z}$ 665.2) indicated that a tetrasaccharide was connected to the 6-arm. Other assignments were the same as in $\mathrm{Man}_{5} \mathrm{GlcNAc}_{2}$, and the predicted structure is shown in Figure 5a-1.

The $\mathrm{MS}^{2}$ spectrum of APTS-labeled $\mathrm{Man}_{8} \mathrm{GlcNAc}_{2}$ is shown in Figure 5b. Three terminal (two 1-2, one 1-3 linked) and three internal mannoses (1-3, 1-6, 1-2 linked) were observed (Supplemental Table S1). The characteristic ion ${ }^{1,4} \mathrm{X}_{3 \beta} / \mathrm{Y}_{3 \alpha}(\mathrm{m} / z$ 560.5) corresponds to an internal 1-3 linked mannose with the loss of the 6-arm of the first branch. It suggested that a trisaccharide was connected to the first branch through a 1-3 linkage. This assignment is consistent with the assignment based on the $\mathrm{C}_{4} / \mathrm{Z}_{3 \beta}-\mathrm{H}$ ion $(\mathrm{m} / z$ 809.2) observed in $\mathrm{ABEE}$ derivative. The ions at $m / z 705.6\left({ }^{0,2} \mathrm{X}_{5 \beta} / \mathrm{Y}_{3 \alpha}\right)$ and $m / z$ $696.6\left({ }^{0,2} \mathrm{X}_{5 \beta}-\mathrm{H}_{2} \mathrm{O} / \mathrm{Y}_{3 \alpha}\right)$ correspond to a terminal 1-2 linked mannose with a loss of the 6-arm. It suggested that the terminal linkage of the 3-linked trisaccharide was a 1-2 linkage (Figure 5a-2). The ions at $\mathrm{m} / \mathrm{z} 897.6$ $\left({ }^{2,4} \mathrm{X}_{4 \alpha^{\prime \prime}} / \mathrm{Y}_{4^{\prime}}\right)$ and $m / z 883.4\left({ }^{0,3} \mathrm{X}_{4 \alpha^{\prime \prime}} / \mathrm{Y}_{4^{\prime}}\right)$ correspond to a terminal 1-3 mannose with loss of a disaccharide. It suggests that $\mathrm{Man}_{8} \mathrm{GlcNAc}_{2}$ contained three terminal mannoses (Figure 5a-3). The fragment ions ${ }^{0,2} \mathrm{X}_{5 \alpha}$ or $5 \beta$ $(m / z \quad 1029.7)$ and ${ }^{0,2} \mathrm{X}_{5 \alpha^{\prime}}$ or $5 \beta^{-} \mathrm{H}_{2} \mathrm{O}(\mathrm{m} / \mathrm{z} 1020.7)$ resulted from a terminal 1-2 linked mannose suggested that the terminal linkage of the 6-arm was a 1-2 linkage (Figure 5a-4).

The fragment ion ${ }^{1,4} \mathrm{X}_{3 \beta} / \mathrm{Y}_{3 \alpha}$ suggested that position C6 of the 3-linked internal mannose was not substituted 
(a)

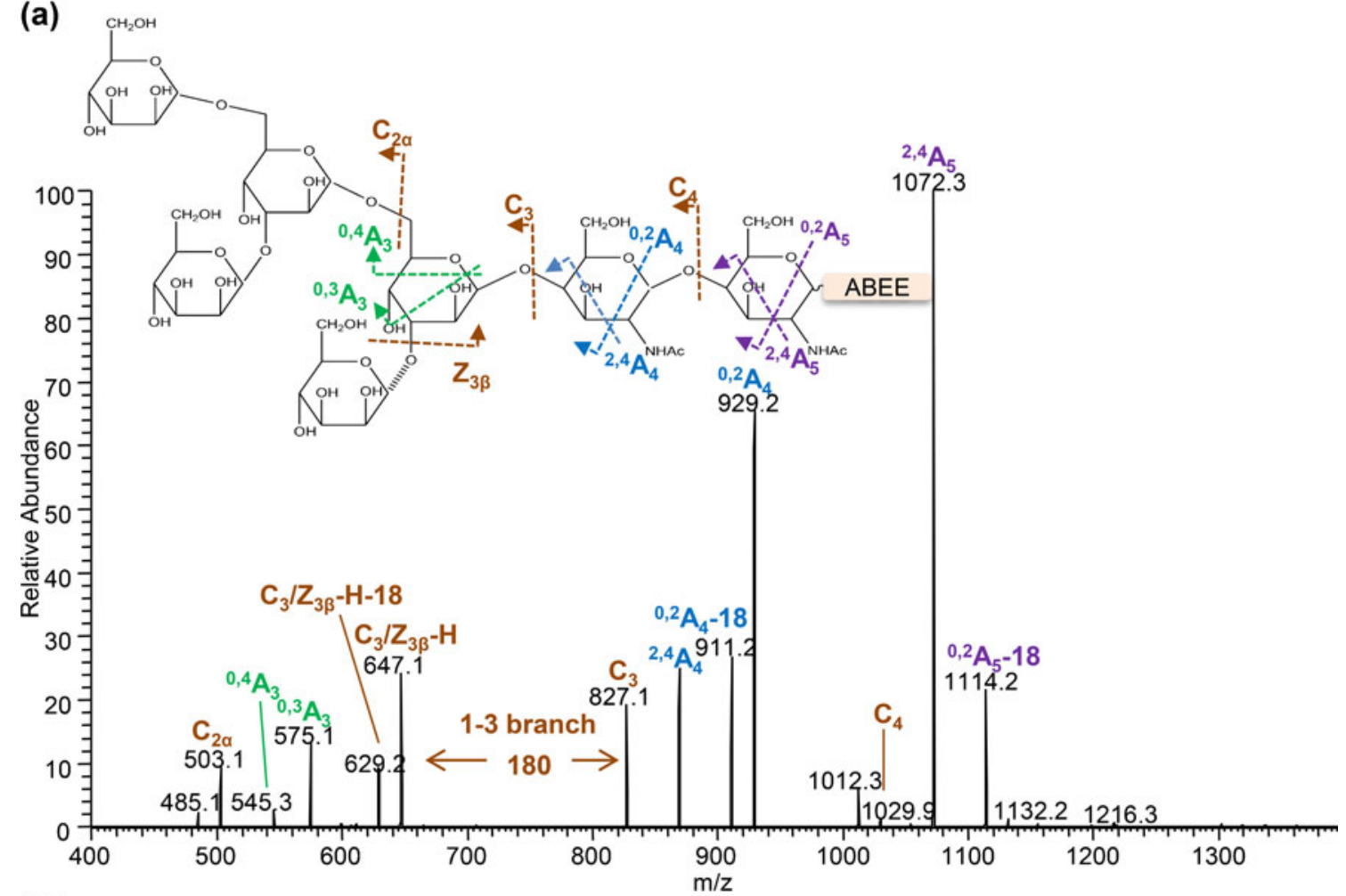

(b)

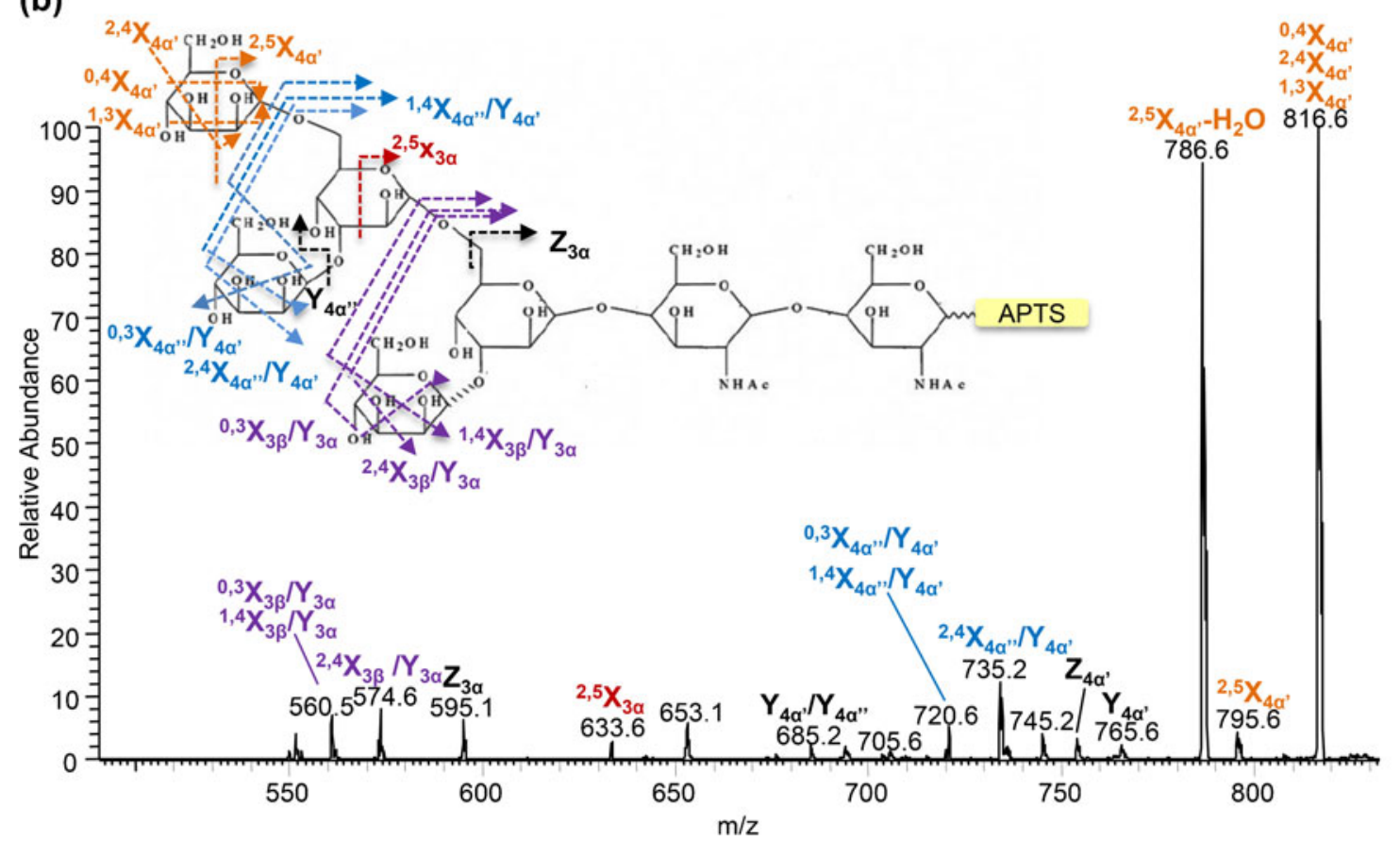

Figure 3. $\mathrm{MS}^{2}$ negative ESI mass spectra of ABEE- and APTS-labeled Man $\mathrm{GlcNAc}_{2}$. (a) $\mathrm{MS}^{2}$ spectrum of ABEE-labeled $\mathrm{Man}_{5} \mathrm{GlcNAc}_{2}\left([\mathrm{M}-\mathrm{H}]^{-}, m / z\right.$ 1380.2 $\rightarrow$ ). (b) $\mathrm{MS}^{2}$ spectrum of APTS-labeled Man ${ }_{5} \mathrm{GlcNAc}_{2}\left([\mathrm{M}-3 \mathrm{H}+\mathrm{Na}]^{2-}, m / z\right.$ 846.5 $\rightarrow$ )

(otherwise, a fragment ion would appear two hexoses higher than $\mathrm{m} / \mathrm{z}$ 560.5). Therefore, the internal 1-6 linked mannose was assigned to the second branched sugar (Figure 5a-5). The second linkage of 3-arm was assigned as an internal 1-2 linkage (Figure 5a-6). Because of the lack of a standard with internal 1-2 linkage, the assignment was based on two sources of indirect evidence. The 1-6 linkage was ruled out as described 
(a)

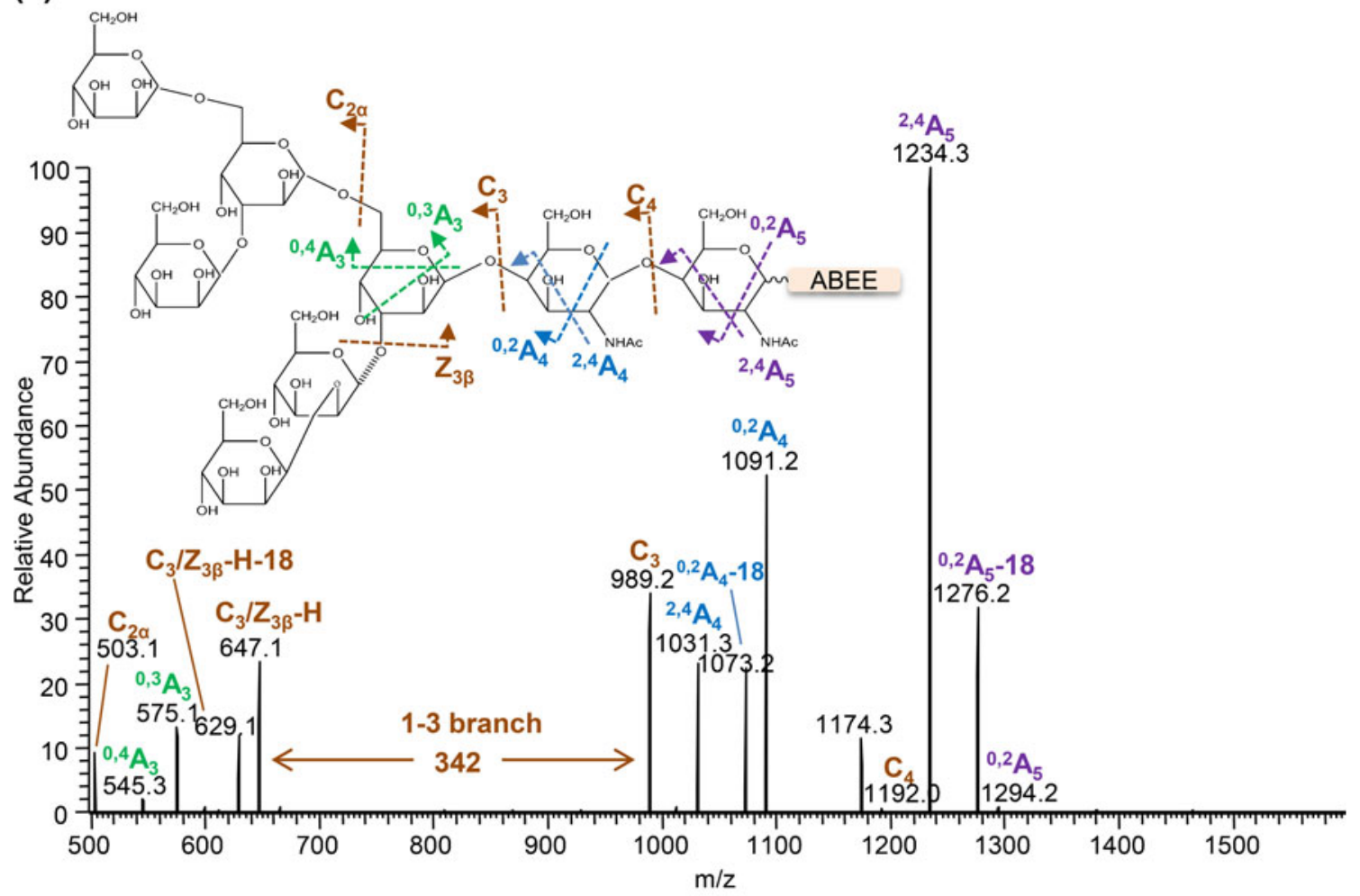

(b)

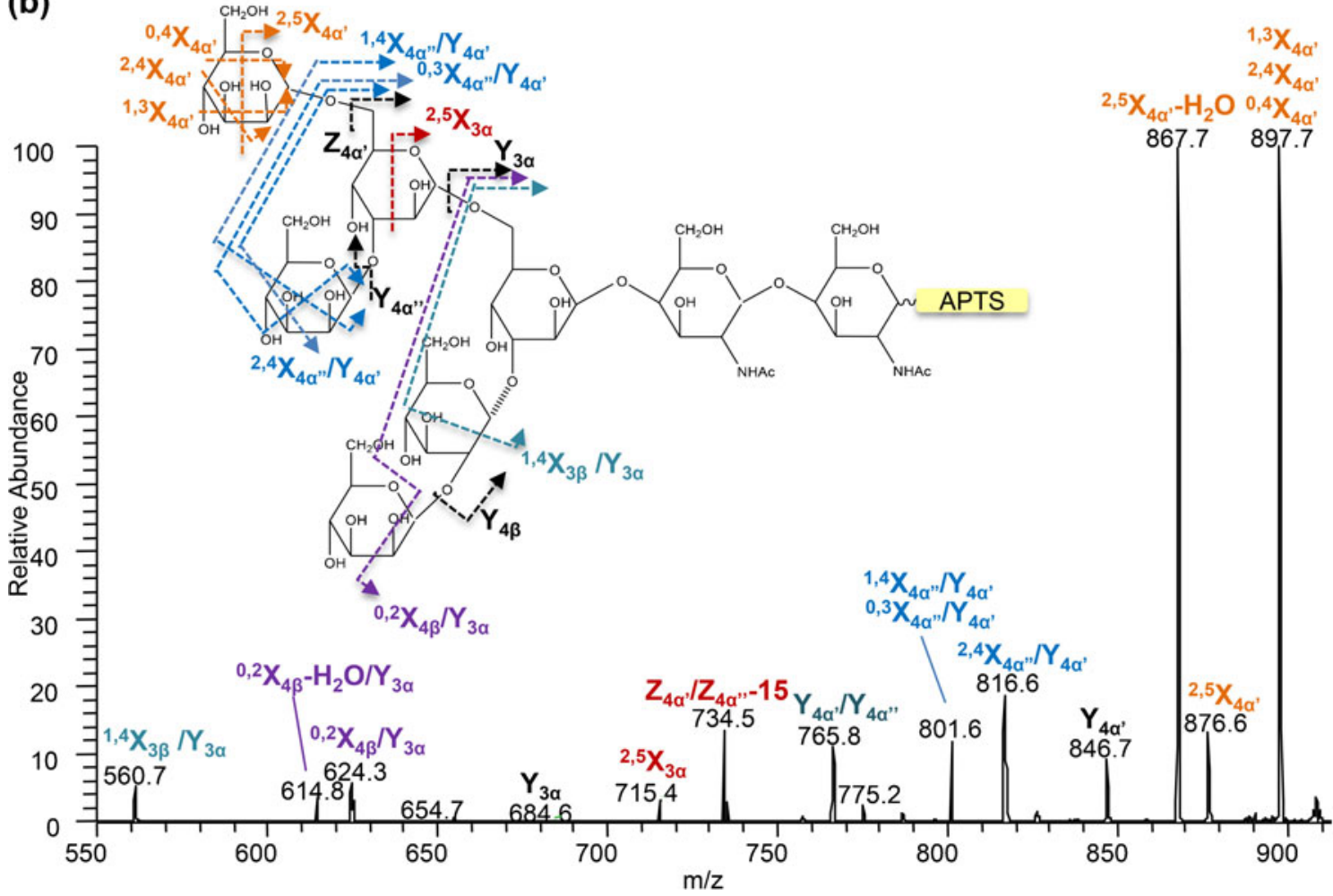

Figure 4. $\mathrm{MS}^{2}$ negative ESI mass spectra of $\mathrm{ABEE}$ - and APTS-labeled Man $\mathrm{GICNAc}_{2}$. (a) $\mathrm{MS}^{2}$ spectrum of $\mathrm{ABEE}-$ labeled $\mathrm{Man}_{6} \mathrm{GlcNAc}_{2}\left([\mathrm{M}-\mathrm{H}]^{-}, m / z\right.$ 1542.3 $\rightarrow$ ). (b) $\mathrm{MS}^{2}$ spectrum of APTS-labeled Man ${ }_{6} \mathrm{GlcNAc}_{2}\left([\mathrm{M}-3 \mathrm{H}+\mathrm{Na}]^{2-}, m / z\right.$ 927.5 $\left.\rightarrow\right)$

in the first sentence of this paragraph. Due to the absence of fragments derived from either internal 1-4 or
1-3 linked mannose on the 3-arm, the second linkage was assigned as a 1-2 linkage. This assignment was also 
(a)

(1)

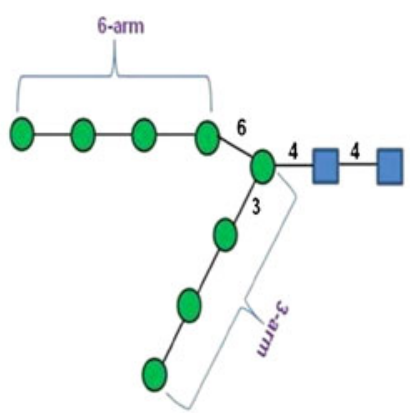

(4)

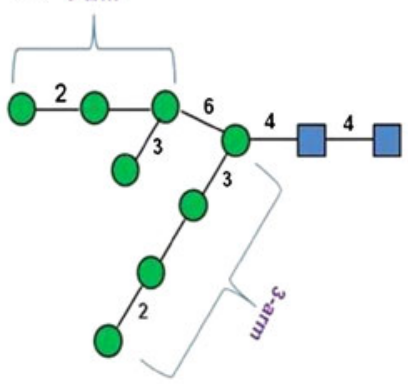

(2)

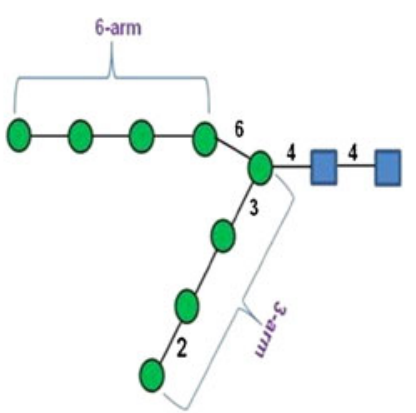

(5) 6-arm

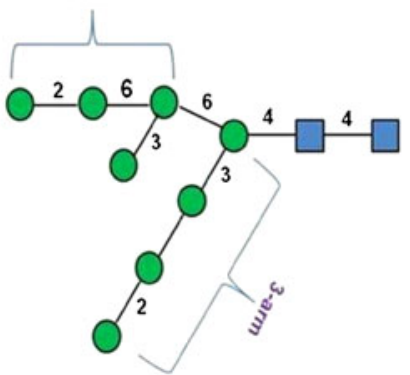

(3)

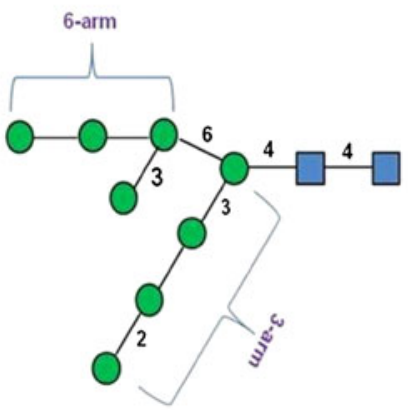

(6) 6-arm

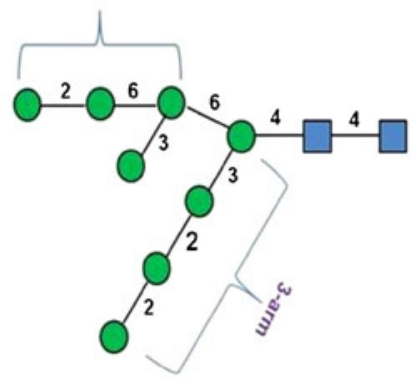

(b)

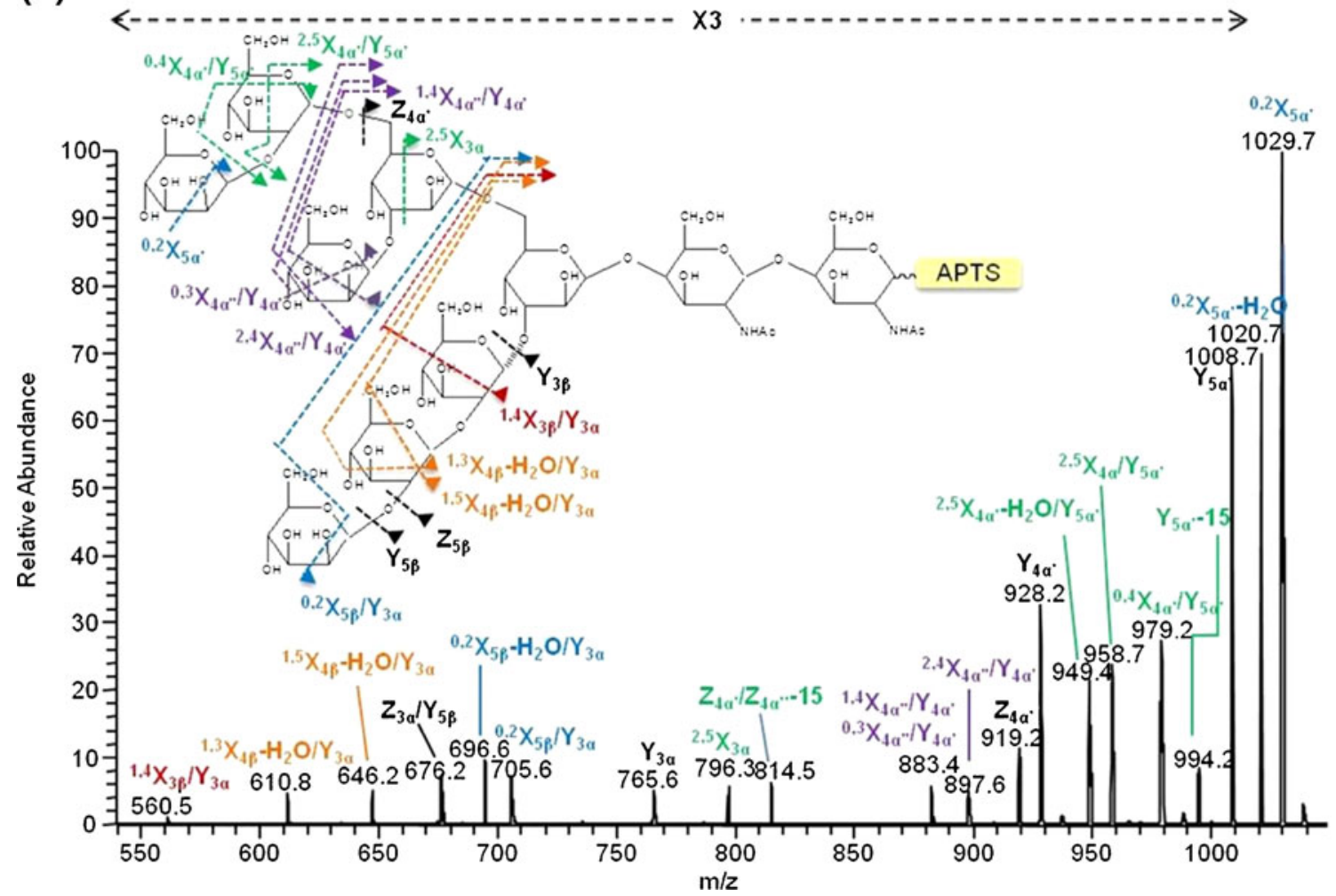

Figure 5. (a) Schematic representation of predicted structure of $\mathrm{Man}_{8} \mathrm{GlcNAc}_{2}$ (1)-(6) based on the product ions of APTSlabeled $\mathrm{Man}_{8} \mathrm{GlcNAc}_{2}$. (b) $\mathrm{MS}^{2}$ spectrum of APTS-labeled Man ${ }_{8} \mathrm{GlcNAc}_{2}\left([\mathrm{M}-3 \mathrm{H}+\mathrm{Na}]^{2-}, \mathrm{m} / z\right.$ 1089.5 $)$

supported by observation of the ${ }^{1,3} \mathrm{X}_{4 \beta}-\mathrm{H}_{2} \mathrm{O} / \mathrm{Y}_{3 \alpha}(\mathrm{m} / \mathrm{z}$ 646.7) and ${ }^{1,5} \mathrm{X}_{4 \beta}-\mathrm{H}_{2} \mathrm{O} / \mathrm{Y}_{3 \alpha}(\mathrm{m} / z$ 610.2) ions, which differ from the characteristic ions of internal 1-3, 1-4, and 1-6 linkages and were tentatively assigned as ions specific to internal 1-2 linkage. As a result, the linkages and branches of $\mathrm{Man}_{8} \mathrm{GlcNAc}_{2}$ were assigned. 
(a)

(1)

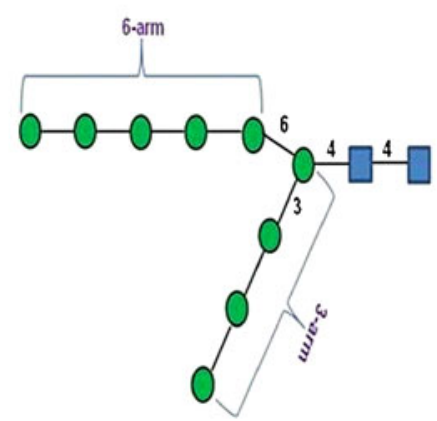

(4)

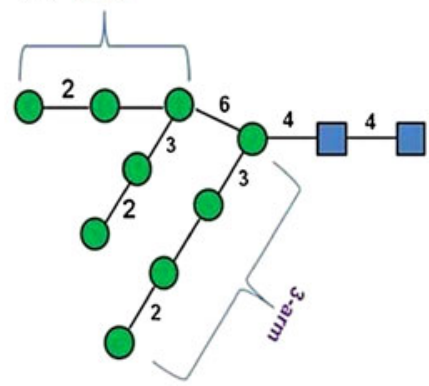

(2)

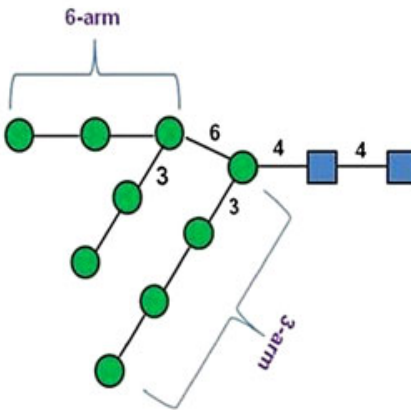

(5) 6-arm

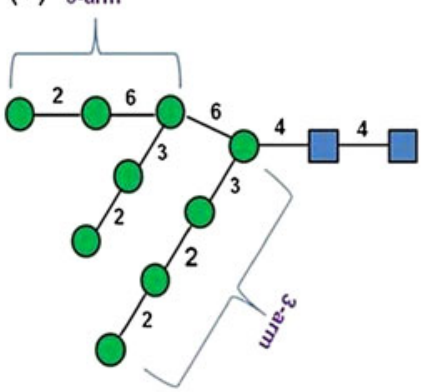

(3)

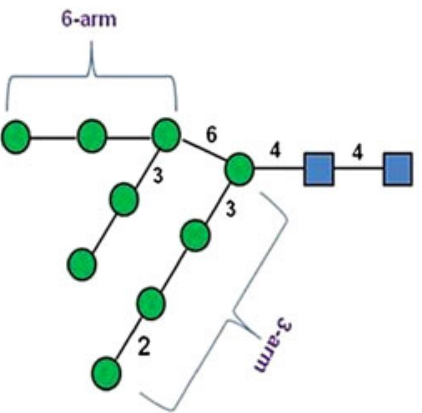

(b)

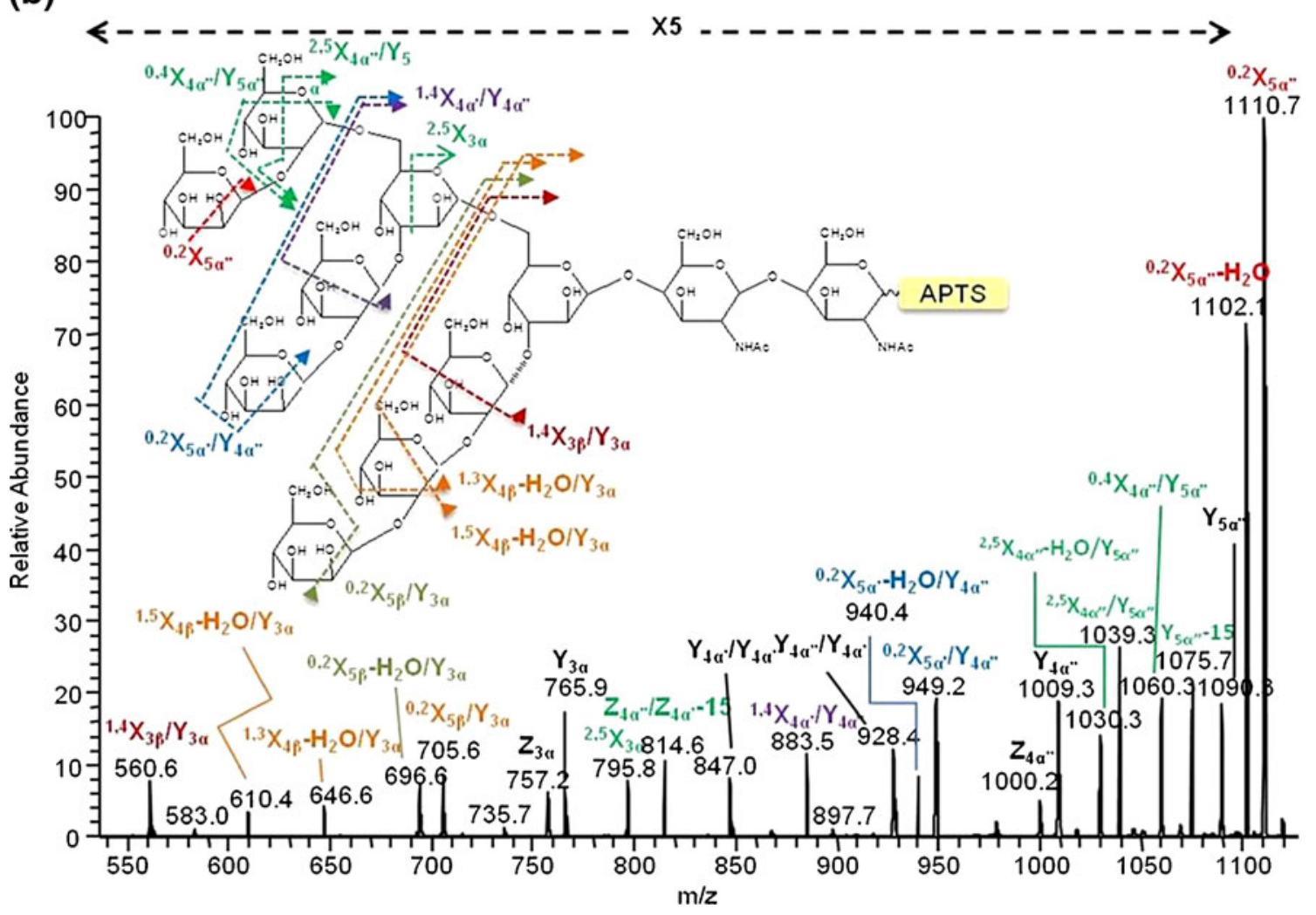

Figure 6. (a) Schematic representation of predicted structure of $\mathrm{Man}_{9} \mathrm{GlcNAc}_{2}$ (1)-(5) based on the product ions of APTS-

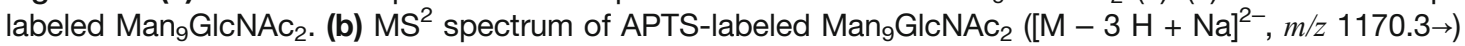

In this analysis of $\mathrm{Man}_{8} \mathrm{GlcNAc}_{2}$, it is assumed that the mass spectrum was dominated by the most abundant isomer $(84 \%)$. However, it should be cautious with this assumption, because many characteristic ions are of low abundance and the mass spectrum is normalized out of one dimensional plot. 


\section{Analysis of $\mathrm{Man}_{9} \mathrm{GlcNAc}_{2}$ Based on APTS and ABEE-Labeling}

The fragment ion $\mathrm{C}_{3 \alpha}\left(\mathrm{m} / z\right.$ 827.1) in $\mathrm{MS}^{2}$ spectrum of ABEE-labeled $\mathrm{Man}_{9} \mathrm{GlcNAc}_{2}$ (Supplemental Figure S2) suggested that a pentasaccharide was connected to the 6arm of the first branch. Other assignments were the same as in $\mathrm{Man}_{8} \mathrm{GlcNAc}_{2}$, and the predicted structure is shown in Figure 6a-1.

The MS ${ }^{2}$ spectrum of APTS-labeled $\mathrm{Man}_{9} \mathrm{GlcNAc}_{2}$ is shown in Figure $6 \mathrm{~b}$. Three terminal 1-2 linked and four internal mannoses (one 1-6, one 1-2, and two 1-3) were observed (Supplemental Table S2). The characteristic ion ${ }^{1,4} \mathrm{X}_{4 \alpha^{\prime}} / \mathrm{Y}_{4 \alpha^{\prime \prime}}(\mathrm{m} / \mathrm{z} 883.5)$ corresponds to an internal 1-3 linked mannose (second from the terminus) with the loss of a disaccharide. This ion suggested that the 6-arm of the first branched sugar had a second branched sugar, and that a disaccharide was linked to the second branch through a 1-3 linkage (Figure 6a-2). The ions at $\mathrm{m} / z 705.6\left({ }^{0,2} \mathrm{X}_{5 \beta} / \mathrm{Y}_{3 \alpha}\right)$ and $696.6\left({ }^{0,2} \mathrm{X}_{5 \beta}-\mathrm{H}_{2} \mathrm{O} / \mathrm{Y}_{3 \alpha}\right)$ were produced from a terminal 1-2 linked mannose with a loss of a pentasaccharide from the 6arm. It indicated that the terminal linkage of the 3-linked trisaccharide was a 1-2 linkage (Figure 6a-3). The fragment ions ${ }^{0,2} \mathrm{X}_{5 \alpha^{\prime}} / \mathrm{Y}_{4 \alpha^{\prime \prime}}(m / z 949.2)$ and ${ }^{0,2} \mathrm{X}_{5 \alpha^{\prime}}-\mathrm{H}_{2} \mathrm{O} / \mathrm{Y}_{4 \alpha^{\prime \prime}}(m / z$ 940.4) correspond to a terminal 1-2 linked mannose with the loss of a disaccharide. The fragment ions ${ }^{0,2} \mathrm{X}_{5 \alpha^{\prime} \text { or } 5 \beta}(\mathrm{m} / \mathrm{z}$ $1110.7)$ and ${ }^{0,2} \mathrm{X}_{5 \alpha^{\prime}}$ or $5 \beta-\mathrm{H}_{2} \mathrm{O}(\mathrm{m} / z$ 1102.1) correspond to a terminal 1-2 linked mannose with no loss of the sugar. These two series of terminal 1-2 linked fragment ions suggested that the two termini of the second branched sugar were 1-2 linked (Figure 6a-4). The determination of two unassigned linkages in Figure 6b-4 was the same as in $\mathrm{Man}_{8} \mathrm{GlcNAc}_{2}$. As a result, the linkages and branches were assigned (Figure 6a-5)

\section{Analysis of $\mathrm{Man}_{7} \mathrm{GlcNAc}_{2}$ Isomers}

The $\mathrm{Man}_{7} \mathrm{GlcNAc}_{2}$ is a mixture of three isomers with similar abundance. The structures of the isomers and the $\mathrm{MS}^{2}$ spectrum of APTS-labeled $\mathrm{Man}_{7} \mathrm{GlcNAc}_{2}$ were shown in Supplemental Figure S3. Many product ions were observed and some linkage specific fragments suggested that more than one isomer was present in the sample analyzed. For example, the fragments at $m / z 898.2\left({ }^{2,4} \mathrm{X}_{4 \alpha^{\prime \prime}} / \mathrm{Y}_{4 \alpha^{\prime}}\right), m / z 883.1$ $\left({ }^{0,3} \mathrm{X}_{4 \alpha^{\prime \prime}} / \mathrm{Y}_{4 \alpha^{\prime}}\right)$ and at $m / z 816.8\left({ }^{2,4} \mathrm{X}_{4 \alpha^{\prime \prime}} / \mathrm{Y}_{4 \alpha^{\prime}}\right), m / z 801.8$ $\left({ }^{0,3} \mathrm{X}_{4 \alpha^{\prime \prime}} / \mathrm{Y}_{4 \alpha^{\prime}}\right)$ correspond to a terminal 1-3 linked mannose with the loss of a monosaccharide (isomer I) and a disaccharide (isomer III) from the 6-arm, respectively.

The linkage specific fragments were assigned and summarized in Supplemental Table S3. As can be seen, linkage specific fragments related to the three isomers were observed. However, it should be mentioned that without knowing the structure of the isomers, some fragments could be assigned to different structures. For example, fragments labeled with $(\mathrm{X})$ could be assigned as the linkage specific fragments with an assumptive structure of $\mathrm{X}$. As a result, when this approach is used to analyze an unknown sample, purification before $\mathrm{MS}^{2}$ analysis is highly recommended.

\section{Conclusions}

Negative-ion ESI-MS/MS analysis of APTS closed-ring labeled oligosaccharides showed that linkages can be assigned for oligosaccharides up to six sugar residues. Unlike the ABEE labeling, the linkage information is mainly derived from the non-reducing end. This complementary information produced by ABEE- and APTS-labeled oligosaccharides was utilized to delineate the linkages and branches of larger oligosaccharides. The analysis of N-linked glycans from ribonuclease $\mathrm{B}$ showed that the linkages and branches for $\mathrm{Man}_{5} \mathrm{GlcNAc}_{2}, \mathrm{Man}_{6} \mathrm{GlcNAc}_{2} \mathrm{Man}_{8} \mathrm{GlcNAc}_{2}$ and $\mathrm{Man}_{9} \mathrm{GlcNAc}_{2}$ could be deduced from the combined information obtained from $\mathrm{MS}^{2}$ of ABEE- and APTS-labeled oligosaccharides. It is worth to mention that low-energy $\mathrm{MS}^{2}$ instead of high-energy $\mathrm{MS}^{2}$ or $\mathrm{MS}^{\mathrm{n}}$ is used in this study. As a result, this approach can be adopted by laboratories equipped with triple quadrupole, quadrupole time-of-flight (Q/TOF) or ion trap mass spectrometer. High-mannose glycans studied in this approach are well characterized oligosaccharides. There could be many other structural isomers. Isomers not examined in this approach may present identical or very similar mass spectra. Therefore, the assignments may not be fully conclusive when this approach is applied to true unknown.

\section{Acknowledgments}

The authors acknowledge support for this work by the National Research Council of the Republic of China.

\section{References}

1. Li, H., Sharon, N.: Protein glycosylation: Structural and functional aspects. Eur. J. Biochem. 218, 1-27 (1993)

2. Dwek, R.A.: Glycobiology: Toward understanding the function of sugars. Chem. Rev. 96, 683-720 (1996)

3. Kukuruzinska, M.A., Lennon, K.: Protein N-glycosylation: Molecular genetics and functional significance. Crit. Rev. Oral Biol. Med. 9, 415448 (1998)

4. Bernfield, M., Gotte, M., Park, P.W., Reizes, O., Fitzgerald, M.L., Lincecum, J., Zako, M.: Functions of cell surface heparan sulfate proteoglycans. Annu. Rev. Biochem. 68, 729-777 (1999)

5. Sugahara, K., Kitagawa, H.: Recent advances in the study of the biosynthesis and functions of sulfated glycosaminoglycans. Curr. Opin. Struct. Biol. 10, 518-527 (2000)

6. Helenius, A., Aebi, M.: Intracellular functions of N-linked glycans. Science 291, 2364-2369 (2001)

7. Chaplin, M.F., Kennedy, J.F.: Carbohydrate Analysis, pp. 221-289. Oxford Univ. Press, New York (1994)

8. Tseng, K., Hedrick, J.L., Lebrilla, C.B.: Catalog-library approach for the rapid and sensitive structural elucidation of oligosaccharides. Anal. Chem. 71, 3747-3754 (1999)

9. Chai, W., Lawson, A.M., Piskarev, V.: Branching pattern and sequence analysis of underivatized oligosaccharides by combined MS/MS of singly and doubly charged molecular ions in negative-ion electrospray mass spectrometry. J. Am. Soc. Mass Spectrom. 13, 670-679 (2002)

10. Pfenninger, A., Karas, M., Finke, B., Stahl, B.: Structural analysis of underivatized natural human milk oligosaccharides in the native ion mode by nano-electrospray $\mathrm{MS}^{\mathrm{n}}$. Part 1: Methodology. J. Am. Soc. Mass Spectrom. 13, 1331-1340 (2002) 
11. Morelle, W., Michalski, J.-C.: The mass spectrometric analysis of glycoproteins and their glycan structures. Curr. Anal. Chem. 1, 29-57 (2005)

12. Zhang, Z., Linhardt, R.J.: Sequence analysis of native oligosaccharides using negative ESI tandem MS. Curr. Anal. Chem. 5, 225-237 (2009)

13. Sible, E.M., Brimmer, S.P., Leary, J.A.: Interaction of first row transition metals with a 1-3, a 1-6 mannotriose, and conserved trimannosyl core oligosaccharides: A comparative electrospray ionization study of doubly and singly charged complexes. J. Am. Soc. Mass Spectrom. 8, 32-42 (1997)

14. König, S., Leary, J.A.: Evidence for linkage position determination in cobalt coordinated pentasaccharides using ion trap mass spectrometry. J. Am. Soc. Mass Spectrom. 9, 1125-1134 (1998)

15. Gaucher, S.P., Leary, J.A.: Determination anomericity of the glycosidic bond in $\mathrm{Zn}$ (II)-diethylenetriamine-disaccharide complex using $\mathrm{MS}^{\mathrm{n}}$ in a quadrupole ion trap. J. Am. Soc. Mass Spectrom. 10, 269-272 (1999)

16. Weiskopf, A.S., Vouros, P., Harvey, D.J.: Characterization of oligosaccharide composition and structure by quadrupole ion trap mass spectrometry. Rapid Commun. Mass Spectrom. 11, 1493-1504 (1997)

17. Weiskopf, A.S., Vouros, P., Harvey, D.J.: Electrospray ionization-ion trap mass spectrometry for structural analysis of complex N-linked glycoprotein oligosaccharides. Anal. Chem. 70, 4441-4447 (1998)

18. Viseux, N., de Hoffmann, E., Domon, B.: Structural assignment of permethylated oligosaccharide subunits using sequential tandem mass spectrometry. Anal. Chem. 70, 4951-4959 (1998)

19. Viseux, N., Costello, C.E., Domon, B.: Post-source decay mass spectrometry: Optimized calibration procedure and structural characterization of permethylated oligosaccharides. J. Mass Spectrom. 34, 364-378 (1999)

20. Prien, J.M., Ashline, D.J., Lapadula, A.J., Zhang, H., Reinhold, V.N.: The high mannose glycans from Bovine Ribonuclease B isomer characterization by ion trap MS. J. Am. Soc. Mass Spectrom. 20, 539556 (2009)

21. Ahn, Y.H., Yoo, J.S.: Malononitrile as a new derivatizing reagent for highsensitivity analysis of oligosaccharides by electrospray ionization mass spectrometry. Rapid Commun. Mass Spectrom. 12, 2011-2015 (1998)

22. Li, D.T., Her, G.R.: Structural analysis of chromophore-labeled disaccharides and oligosaccharides by electrospray ionization mass spectrometry and high-performance liquid chromatography/electrospray ionization mass spectrometry. J. Mass Spectrom. 33, 644-652 (1998)

23. Charlwood, J., Langridge, J., Tolson, D., Birrell, H., Camilleri, P.: Profiling of 2-aminoacridone derivatized glycans by electrospray ionization mass spectrometry. Rapid Commun. Mass Spectrom. 13, 107-112 (1999)

24. Saba, J.A., Shen, X., Jamieson, J.C., Perreault, H.: Effect of 1-phenyl-3methyl-5-pyrazolone labeling on the fragmentation behavior of asialo and sialated n-linked glycans under electrospray ionization conditions. Rapid Commun. Mass Spectrom. 13, 704-711 (1999)

25. Shen, X., Perreault, H.: Electrospray ionization mass spectrometry of $1-$ phenyl-3-methyl-5-pyrazolone derivatives of neutral and n-acetylated oligosaccharides. J. Mass Spectrom. 34, 502-510 (1999)

26. Harvey, D.J.: Electrospray mass spectrometry and fragmentation of nlinked carbohydrates derivatized at the reducing terminus. J. Am. Soc. Mass Spectrom. 11, 900-915 (2000)

27. Li, D.T., Sheen, J.F., Her, G.R.: Structural analysis of chromophorelabeled disaccharides by capillary electrophoresis tandem mass spectrometry using ion trap mass spectrometry. J. Am. Soc. Mass Spectrom. 11, 292-300 (2000)
28. Cheng, H.L., Her, G.R.: Determination of linkages of linear and branched oligosaccharides using closed-ring chromophore labeling and negative ion trap mass spectrometry. J. Am. Soc. Mass Spectrom. 13, 1322-1330 (2002)

29. Cheng, H.L., Pai, P.J., Her, G.R.: Linkage and branch determination of $\mathrm{N}$-linked oligosaccharides using sequential degradation/closed-ring chromophore labeling/negative ion trap mass spectrometry. J. Am. Soc. Mass Spectrom. 18, 248-259 (2007)

30. Harvey, D.J.: Derivatization of carbohydrates for analysis by chromatography; electrophoresis and mass spectrometry. J. Chromatogr. B 879, 1196-1225 (2011)

31. Mechref, Y., Novotny, M.V., Krishnan, C.: Structural characterization of oligosaccharides using MALDI-TOF/TOF tandem mass spectrometry. Anal. Chem. 75, 4895-4903 (2003)

32. Spina, E., Sturiale, L., Romeo, D., Impallomeni, G., Garozzo, D., Waidelich, D., Glueckmann, M.: New fragmentation mechanisms in matrix-assisted laser desorption/ionization time-of-flight/time-of-flight tandem mass spectrometry of carbohydrates. Rapid Commun. Mass Spectrom. 18, 392-398 (2004)

33. Stephens, E., Maslen, S.L., Green, L.G., Williams, D.H.: Fragmentation characteristics of neutral n-linked glycans using a MALDI-TOF/TOF tandem mass spectrometer. Anal. Chem. 76, 2343-2354 (2004)

34. Zaia, J.: Mass spectrometry of oligosaccharides. Mass Spectrom. Rev. 23, 161-227 (2004)

35. Wuhrer, M., Deelder, A.M.: Negative-mode MALDI-TOF/TOF-MS of oligosaccharides labeled with 2-aminobenzamide. Anal. Chem. 77, 6954-6959 (2005)

36. Morelle, W., Slomianny, M.C., Diemer, H., Schaeffer, C., Dorsselaer, A.V., Michalski, J.C.: Structural characterization of 2-aminobenzamidederivatized oligosaccharides using a matrix-assisted laser desorption/ ionization two-stage time-of-flight tandem mass spectrometer. Rapid Commun. Mass Spectrom. 19, 2075-2084 (2005)

37. Lewandrowski, U., Resemann, A., Sickmann, A.: Laser-induced dissociation/high-energy collision-induced dissociation fragmentation using MALDI-TOF/TOF-MS instrumentation for the analysis of neutral and acidic oligosaccharides. Anal. Chem. 77, 3274-3283 (2005)

38. Mechref, Y., Kang, P., Novotny, M.V.: Differentiating structural isomers of sialylated glycans by matrix-assisted laser desorption/ ionization time-of-flight/time-of-flight tandem mass spectrometry. Rapid Commun. Mass Spectrom. 20, 1381-1389 (2006)

39. Domon, B., Mueller, D.R., Richter, W.J.: Tandem mass spectrometric analysis of fixed-charge derivatized oligosaccharides. Org. Mass Spectrom. 29, 713-719 (1994)

40. Packer, N.H., Lawson, M.A., Jardine, D.R., Redmond, J.W.: A general approach to desalting oligosaccharides released from glycoproteins. Glycoconj. J. 15, 737-747 (1998)

41. Lai, C.C., Her, G.R.: Analysis of N-glycosylation of phospholipase A2 from venom of individual bees by microbore high performance liquid chromatography/electrospray mass spectrometry using an ion trap mass spectrometer. J. Chromatogr. B 766, 243-250 (2002)

42. Fu, D., Chen, L., O'Neill, R.A.: A detailed structural characterization of ribonuclease B oligosaccharides by $1 \mathrm{H}$ NMR spectroscopy and mass spectrometry. Carbohydr. Res. 261, 173-186 (1994)

43. Domon, B., Costello, C.E.: A systematic nomenclature for carbohydrate fragmentations in FAB-MS/MS spectra of glycoconjugates. Glycoconj. J. 5, 397-409 (1988) 